\title{
Replacement of cow milk chhana with soy chhana in the preparation of rasomalai
}

\author{
MN I slam*, F Parvin, MS Hossain, A Wadud, MSR Siddiki, MS Khan
}

Department of Dairy Science, Bangladesh Agricultural University, Mymensingh-2202

\begin{abstract}
Four different types of rasomalai were prepared from cow milk chhana (acid curd) with the addition of different levels of soy chhana. The prepared rasomalai were named as 'A' (100\% cow milk chhana), ' $B$ ' ( $75 \%$ cow milk chhana+25\% Soy Chhana), 'C' (50\% cow milk chhana+50\% soy chhana) and 'D' (25\% cow milk chhana $+75 \%$ soy chhana). The qualities of prepared rasomalai were evaluated by using physical and chemical parameters. It was observed that the addition of soy chhana with cow milk chhana decreased the organoleptic score of the prepared rasomalai. The moisture, total solids and carbohydrate content of the sample were not significantly differed, but protein $(p<0.05)$, ash $(p<0.05)$, fat $(p<0.01)$ content and acidity percent $(p<0.01)$ of the samples were significantly decreased in addition of soy chhana with cow milk chhana. Considering the physico-chemical properties of all samples, it was found that most suitable and acceptable quality of rasomalai can be prepared by admixture of $25 \%$ soy chhana and $75 \%$ cow milk chhana
\end{abstract}

Key words: Chhana, cow milk, organoleptic score, soy milk

Bangladesh Animal Husbandry Association. All rights reserved.

Bang. J. Anim. Sci. 2015. 44 (1): 59-63

\section{Introduction}

Milk is the most important food for the people of all ages. Recently, food habit of common people changes to a wide variety of dairy products. A portion of total milk produced in Bangladesh is used for sweetmeat making (Sayedatunnesha et al. 2008). In countries or regions where animal proteins are not available or where the prices of that are beyond the purchasing capacity of the average population, soybeans and soybean products may be used for substitutes of animal protein. The nutritional value of soybean is definitely the biggest factor which makes it the best plant protein alternative to animal protein (cow's milk and meat). Soy protein products offer more than just the obvious economic advantages over animal protein (Hettiarachchy and Kalapathy 1997). In countries or regions where animal proteins are not available or where the prices of meat are beyond the purchasing power of the average population, soybeans and soybean products may be used for their substitutes. Soymilk is the rich creamy milk of whole soybeans with its unique nutty flavor and rich in nutrition. soy milk is available as a plain unflavored beverage or in a variety of flavors including chocolate, vanilla and almond. The soy food products which are widely consumed and accepted by world people are tofu, soymilk and beverages ( $\mathrm{Li}$ and Hsieh, 2004). Due to the acute shortage of milk and other protein rich food of animal origin in Bangladesh, the incidence of protein malnutrition is very high among all types of people (Rakhi et al. 2013). For this purpose low cost processed supplementary food need to be developed in Bangladesh. The composition of soy milk is nearly similar to cow's milk except fat (Rakhi et al. 2013). Considering the availability of soybean, it's cheaper price and nutritional value, attempts can be made to develop technologies to use it as a milk extender or milk substitutes which may reduce the pressure on whole milk and may help to reduce the cost of production of dairy products. The aim of the present study was to check the possibility of using soymilk chhana blends with cow milk chhana for the preparation of rasomalai. For this, the organoleptic and chemical evaluation of the rasomalai prepared from different combination of soymilk and cow milk channa was done. 


\section{Materials and Methods}

The experiment was conducted at the Dairy Chemistry and Technology Laboratory of the Department of Dairy Science, Bangladesh Agricultural University, Mymensingh-2202, Bangladesh during the period of March-June, 2008.

Whole milk was collected from Bangladesh Agricultural University Dairy Farm. Fat and solidsnot-fat (SNF) content of the collected milk were $41.7 \mathrm{~g} / \mathrm{kg}$ and $81.5 \mathrm{~g} / \mathrm{kg}$, respectively. One kilogram of immature soybean were grinded in a soy flour mill. Soy powder/ flour (375g) was dissolved in $3000 \mathrm{ml}$ of water $(125 \mathrm{~g} / 1000 \mathrm{ml}$ water) at room temperature $\left(27-30^{\circ} \mathrm{C}\right)$ by stirring. The soymilk was strained through a fine cloth to separate the residue.

During each trial 1.5 litres of cow milk and $\mathbf{1 . 5}$ litres of soymilk were used separately for the preparation of cow milk chhana and soymilk chhana. At first the milk were heated to boiling for about 10 minutes and thereafter allowed to cool down to $80{ }^{\circ} \mathrm{C}$ and $160-180 \mathrm{ml}$ of $1 \%(\mathrm{v} / \mathrm{v})$ citric acid was added as coagulant. Lumps of milk and soy milk formed as soon as the citric acid was added to the heated milk, which is generally known as chhana. About 5 to 10 minutes after coagulation and settled down of the curd, contents were allowed to cool down at room temperature (about $25{ }^{\circ} \mathrm{C}$ ) and then the coagulum was gradually strained with muslin cloth to allow free drainage of whey. When the transfer of whey was completed, the four corners of the cloth were tied together and the coagulum was then hung for about one and half an hour to complete the drainage of whey. The chhana was then carefully removed and weighted.

Four different types of rasomalai were prepared from different combinations of cow milk chhana and soy milk chhana as shown in Table 1 . The required quantity of chhana (Table 1 ), flour (5\%) and baking powder $(1.5 \%)$ were kneaded in order to obtain the desired body and texture. The consistency of the kneaded mass was such that the prepared balls had smooth surface without any sign of crack. Two $\mathrm{kg}$ of sugar was dissolved in $1 \mathrm{~kg}$ of water and heated until clarified sugar syrup obtained. To make the syrup clear, small amount of milk (about $10 \mathrm{ml}$ ) was added to it during boiling and the resulted blackish foam on the top was removed.

Table 1. Different combinations of cow milk chhana and soy milk chhana to prepare rasomalai

\begin{tabular}{ccc}
\hline Types of rasomalai & Cow milk chhana & Soy milk chhana \\
\hline A & $150 \mathrm{gm}(100 \%)$ & $0(0 \%)$ \\
B & $113 \mathrm{gm}(75 \%)$ & $37 \mathrm{gm}(25 \%)$ \\
C & $75 \mathrm{gm}(50 \%)$ & $75 \mathrm{gm}(50 \%)$ \\
D & $37 \mathrm{gm} \mathrm{(25 \% )}$ & $113 \mathrm{gm}(75 \%)$ \\
\hline
\end{tabular}

A little portion of the syrup was then taken out and was kept in a stainless steel pan with a depth of $25 \mathrm{~cm}$ which was used to adjustment of concentration of syrup at boiling golla. The prepared chhana balls were cooked in the remaining sugar syrup for 25-30 min. The balls were boiled such a way that there was enough space for moving the balls freely, especially when swelled. The heat was so controlled that the balls constantly covered with syrup foam. During the cooking period cold water was sprinkled at a regular interval to maintain the concentration of the sugar syrup.

During the preparation of malai, 1.5 litres of cow milk and 1.5 litres of soy milk were taken separately into two iron pans. Four types of malai were prepared from different combinations of the cow milk and soy milk. The proportion of cow milk and soy milk used in different malai preparation was similar to that of the chhana used in different golla. Eighty $\mathrm{g}$ of sugar, 4 and/or 5 pieces of cardamom and 2-3 drops of strawberry flavor (Rayner and Co. Ltd., London, England) were added during heating the milk. The flavoring substance was used to remove the beany flavors of the soybean. The volume of milk was reduced to half by boiling, and then malai was ready to cook golla. Small balls of golla were cooked in hot malai for 3-5 min. Then the rasomalai was prepared and it was allowed to cool. After 5-6 hours, rasomalai was ready for consumption. 
The organoleptic evaluations of the prepared rasomalai samples were performed with the help of eight members expert panel of judges. For this a 100 marks score card (modified from AOAC, 2003) was used, composed of flavor (45), body and texture (30), color and appearance (15) and taste score (10). For chemical quality, the samples were analyzed in the laboratory for their total solids $(\mathrm{g} / \mathrm{kg})$, fat $(\mathrm{g} / \mathrm{kg})$, protein $(\mathrm{g} / \mathrm{kg})$, carbohydrate $(\mathrm{g} / \mathrm{kg})$, ash $(\mathrm{g} / \mathrm{kg})$, and acidity $(\%)$ content.

Total solids, crude protein and ash content of the different types of rasomalai were determined according to (AOAC 2003). Fat and acidity content were determined by Babcock and titration method, respectively using the procedure described by Aggarwala and Sharma (1961). Carbohydrate content was determined by deduction of the aggregate of all other constituents from 100.

One way analyses of variance was done by using SAS (Statistical Analysis System, (version: 9.4) program. The differences among sample means were compared by LSD value.

\section{Results and Discussion}

The score for flavor, body and texture, colour and appearance and taste of the samples are presented in Table 2. Each of them was gradually decreased with the increased proportion of soy chhana. Sample $C$ and $D$ had more beany flavor due to the more presence of soy chhana. In terms of body and texture, highest score ( $\mathrm{A}$ and $B$ samples) indicate the soft and spongy body and texture whereas lowest score ( $C$ and $D$ samples) indicates coarse body. Similar types of work were conducted by Sayedatunnesha et al. (2008) in rasomalai of cow and buffalo milk, Katara and Bhargava (1990) in rasogolla, Chanda et al. (2002) and Parvin (2007) in soy based rosogolla. The variations in color and appearance were probably due to cooking syrup for each type of rasomalai and also due to different levels of soy chhana addition. The color of C and D type rasomalai become slightly darker (brick color) due to the addition of more soy chhana. In terms of taste, D type sample was significantly low because of the presence of high percentage of soy chhana which decreased the fat percentage in rasomalai. The fat percent of soy milk is lower than cow milk (Rakhi et al. 2013) and fat is the one of the important contributor of taste to food (Bhattacharya and Raj 1980). Sensory attributes of rasomalai prepared from mixing of soy and cow chhana are given in the Table 3 . The organoleptic score decreased among the different types of rasomalai samples with the increase level of soy chhana. Rasomalai prepared by using $100 \%$ cow milk chhana (A type) had the highest score among 4 types of rasomalai. The organoleptic score of A type $(100 \%$ cow milk chhana) and B type rasomalai (75\% cow milk chhana $+25 \%$ soy chhana) was in reasonable range and $B$ and $C$ were found very close. Soy chhana have beany flavor and also contains more moisture than cow milk chhana. Due to high moisture content, the structure of prepared rasomalai became flattened. For these reasons the organoleptic scores were lower in C and D type rasomalai where soy chhana were used at the rate of 50 and $75 \%$, respectively.

Table 2. Physical evaluation of different rasomalai samples (total score 100)

\begin{tabular}{lcccc}
\hline \multirow{2}{*}{ Parameters } & \multicolumn{5}{c}{ Types of rasomalai (Mean \pm SE) } \\
\cline { 2 - 5 } & $\mathrm{A}$ & $\mathrm{B}$ & $\mathrm{C}$ & $\mathrm{D}$ \\
\hline Flavor (45) & $41.38^{\mathrm{a}} \pm 0.99$ & $39.27^{\mathrm{b}} \pm 0.25$ & $38.02^{\mathrm{b}} \pm 1.33$ & $33.58^{\mathrm{c}} \pm 4.13$ \\
BT (30) & $27.00^{\mathrm{a}} \pm 1.00$ & $25.43^{\mathrm{b}} \pm 0.97$ & $24.52^{\mathrm{b}} \pm 0.65$ & $21.58^{\mathrm{c}} \pm 2.40$ \\
CA (15) & $13.53^{\mathrm{a}} \pm 0.50$ & $12.55^{\mathrm{a}} \pm 0.23$ & $11.55^{\mathrm{b}} \pm 0.61$ & $10.35^{\mathrm{b}} \pm 0.98$ \\
Taste (10) & $8.52^{\mathrm{a}} \pm 0.28$ & $7.68^{\mathrm{ab} \pm 0.50}$ & $7.33^{\mathrm{b}} \pm 0.58$ & $6.17 \mathrm{c} \pm 0.49$ \\
Total score & $90.43^{\mathrm{a}} \pm 2.77$ & $84.93^{\mathrm{b}} \pm 1.95$ & $81.42^{\mathrm{b}} \pm 2.94$ & $71.68^{\mathrm{c}} \pm 7.61$ \\
\hline
\end{tabular}

$A$, rasomalai made from $100 \%$ cow milk chhana; $B$, rasomalai made from $75 \%$ cow milk chhana $+25 \%$ soy-chhana; $C$, rasomalai made from $50 \%$ cow milk chhana $+50 \%$ soy-chhana; $D$, rasomalai made from $25 \%$ cow milk chhana $+75 \%$ soy-chhana; $B T$, body and texture; $C A$, color and appearance; Means with different superscripts in the same row differ significantly $(p<0.01)$ 


\section{Rasomalai from cow and soy milk chhana}

Table 3. Comparison of organoleptic quality of four different types of rasomalai (perfect score 100)

\begin{tabular}{lllllll}
\hline Types & Flavor & Body and texture & Color and appearance & Taste & Score & Remarks \\
\hline A & Pleasant & Soft and spongy & White and round & Pleasant & 90.43 & Excellent \\
B & Pleasant & Soft and spongy & White and round & Pleasant & 84.93 & Good \\
C & Pleasant & Soft and spongy & Brick color and slightly flatten & Pleasant & 81.42 & Good \\
D & Pleasant but lacks fine flavor & Coarse and hard & Dull white (brick color) and flatten & Not so pleasant & 71.68 & Fair \\
\hline
\end{tabular}

A, rasomalai made from $100 \%$ cow milk chhana; $B$, rasomalai made from $75 \%$ cow milk chhana $+25 \%$ soy-chhana; $C$, rasomalai made from $50 \%$ cow milk chhana $+50 \%$ soy-chhana; $D$, rasomalai made from $25 \%$ cow milk chhana $+75 \%$ soy-chhana

The moisture, total solids, protein, carbohydrate, ash and acidity content of the prepared rasomalai samples are compiled in Table-4. It was observed that the moisture, total solids and carbohydrate content of the sample were not significantly different $(p>0.05)$. Whereas, protein $(p<0.05)$, ash $(p<0.05)$, fat $(p<0.01)$ content and acidity percent $(p<0.01)$ of the sample were significantly decreased due to the addition of different level of soy chhana.

Table 4. Comparison of chemical composition $(\mathrm{g} / \mathrm{kg})$ of $A, B, C$ and $D$ types of rasomalai

\begin{tabular}{lcccc}
\hline \multirow{2}{*}{ Parameters } & \multicolumn{4}{c}{ Types of rasomalai (Mean \pm SE) } \\
\cline { 2 - 5 } & $\mathrm{A}$ & $\mathrm{B}$ & $\mathrm{C}$ & $\mathrm{D}$ \\
\hline $\begin{array}{l}\text { Moisture } \\
(\mathrm{g} / \mathrm{kg})\end{array}$ & $536.6 \pm 0.93$ & $553.4 \pm 1.04$ & $565.9 \pm 2.37$ & $560.1 \pm 4.14$ \\
\hline $\begin{array}{l}\text { Total solids } \\
\text { (g/kg) }\end{array}$ & $463.4 \pm 0.93$ & $446.6 \pm 1.04$ & $439.9 \pm 2.40$ & $434.3 \pm 4.14$ \\
\hline Protein (g/kg) & $45.4^{\mathrm{bc} \pm 0.26}$ & $46.7^{\mathrm{b} c} \pm 0.21$ & $49.1^{\mathrm{b}} \pm 0.19$ & $52.6^{\mathrm{a}} \pm 0.34$ \\
\hline $\begin{array}{l}\text { Carbohydrate } \\
\text { (g/kg) }\end{array}$ & $36.67 \pm 0.96$ & $35.43 \pm 0.68$ & $35.13 \pm 2.18$ & $34.87 \pm 4.51$ \\
\hline Ash (g/kg) & $8.6^{\mathrm{a} \pm 0.06}$ & $6.9^{\mathrm{b}} \pm 0.11$ & $5.1^{\mathrm{bc} \pm 0.28}$ & $4.2^{\mathrm{bc} \pm 0.09}$ \\
\hline Fat (g/kg) & $63.7^{\mathrm{a}} \pm 0.23$ & $48.7^{\mathrm{b}} \pm 0.35$ & $33.9^{\mathrm{b}} \pm 0.60$ & $20.6^{\mathrm{c}} \pm 0.57$ \\
\hline Acidity (\%) & $0.12 \pm 0.68$ & $0.15 \pm 0.01$ & $0.17 \pm 0.02$ & $0.18 \pm 0.02$ \\
\hline
\end{tabular}

A, rasomalai made from $100 \%$ cow milk chhana; $B$, rasomalai made from $75 \%$ cow milk chhana $+25 \%$ soy-chhana; $C$, rasomalai made from $50 \%$ cow milk chhana $+50 \%$ soy-chhana; $D$, rasomalai made from $25 \%$ cow milk chhana $+75 \%$ soy-chhana; Means with different superscripts in the same row differed significantly $\left({ }^{*}, p<0.05\right)$

The protein content gradually increased with the increase level of soy chhana in the prepared sample due to high protein content of soy chhana (Rakhi et al. 2013). As per Bangladesh Standard Testing Institute (BSTI 1993), the protein content of rasomalai should not be less than $5 \%$. Sayedatunnesha et al. 2008 reported the average protein content of cow milk and buffalo milk rasomalai were 61.67 and $84.00 \mathrm{~g} / \mathrm{kg}$, respectively. So the protein content of rasomalai was in the acceptable range.

The fat content of A, B, C and D types of rasomalai were gradually decreased with the increase of soy chhana in rasomalai. Soy chhana had less content of fat and that was the reason of lowering the fat content of rasomalai (Parvin, 2007). Chung (1995), Katra and Bhargava (1994) also reported that chhana containing more soy milk solids had a lower percentage of fat. The carbohydrate content of different rasomalai sample was decreased with addition of soy chhana. It was observed that the carbohydrate content of rasomalai sample was gradually decreased due to have lower percentage of carbohydrate content in soy milk. The carbohydrate content of milk is usually $4.9 \%$ and for soy milk, it is $3.2 \%$ (Swaminathan and Bhargava 1959). Although the carbohydrate content of four types of rasomalai were different but all types of sample were suitable for consumption in respect of carbohydrate content. A significant differences $(p<0.05)$ were found among the ash content and the acidity content $(p<0.01)$ of different samples of rasomalai. Increased acidity was found due to addition of soy chhana with cow milk chhana Jeoun et al. (1995) reported that the addition of soy chhana and brown rice to whole chhana that stimulated acid production and growth of lactic acid bacteria.

\section{Conclusion}

It was concluded from the results of all parameters that acceptable quality of rasomalai could be prepared from $75 \%$ cow milk chhana+ $25 \%$ soy chhana. Type C rasomalai (50\% cow milk chhana $+50 \%$ soy chhana) was inferior to $A$ and B type rasomalai. D type (25\% cow milk chhana $+75 \%$ soy chhana) rasomalai was poor quality. Finally, it may be suggested that soy 
chhana could be used to replace whole milk for making rasomalai and addition of $25 \%$ soy chhana with $75 \%$ cow milk chhana produced rasomalai which was nearly similar to the quality of rasomalai prepared from $100 \%$ cow milk chhana. However, C type rasomalai (50\% cow milk chhana $+50 \%$ soy chhana) could also be used.

\section{References}

Aggarwala AC, Sharma RM (1961). A Laboratory Manual of milk Inspection, Bombay, Calcutta, New Delhi, India. P. 14

AOAC (2003). Association of Official Agricultural Chemists. Official Methods of Analysis. $10^{\text {th }}$ Edition. Washington, DC, USA.

Bhattacharya DC, Raj D (1980). Studies on the production of rasogolla part I traditional method. Indian J ournal of Dairy Science, 33 : 237-243.

BSTI (1993). Bangladesh Standard Specification for rasogolla. Bangladesh Standards and Testing Institution, Dhaka. P. 3.

Chanda T, Islam MN, Debnath GK, Kober AKMH, Chanda GC (2002). Preparation of rasogolla from different proportionate mixture of cow's milk and soy-milk curd. Bangladesh Journal of Animal Science, 31: 99 - 106.

Chung CW (1995). Nutritious composition containing raw soybean milk and raw cow's milk. Soybean Abstract, 20: 50.

Hettiarachchy N, Kalapathy U (1997). Soybean Protein Products. Soybeans, Springer
International Publishing AG, Chapman and Hall, USA. P. 379-411.

J eoun K, Kim Y, Park S, Park SI (1995). Preparation and characteristics of yoghurt from milk with added soymilk and brown rice. Korean Journal of Science and Technology, 27: 4755.

Katara RV, Bhargava VN (1990). Studies of the manufacture of Rasogolla from buffalo and soy milk blends. Asian Journal of Dairy Research, 9: 175 -180.

Li J, Hsieh YHP (2004). Traditional Chinese food technology and cuisine. Asia Pacific Journal of Clinical Nutrition, 13: 147-155.

Parvin S (2007). Preparation of Rasogolla from standardized soy milk with addition of different level of cow milk. MS Thesis, Department of Dairy Science, Bangladesh Agricultural University, Mymensingh.

Rakhi TA, Islam MN, Hoque SAM, Rahman MM (2013). Development of mango flavored Soy Dahi. Bangladesh Journal Animal Science, 42: 44-48

Sayedatunnesha, Wadud A, Islam MN, Islam MA, Hossain MA (2008). Comparative study of the quality of rasomalai manufactured from cow and buffalo milk. Bangladesh Journal Animal Science, 37: 57-62.

Swaminathan M, Bhagavan RK (1959). "Our Food" Ganesh and Co. (Aladras) Private Limited, Madras, India, P. 88. 